\title{
Expression of HNF4alpha in the human and rat choroid plexus - Implications for drug transport across the blood-cerebrospinal-fluid (CSF) barrier
}

\author{
Monika Niehof ${ }^{1}$ and Jürgen Borlak*1,2
}

Address: ${ }^{1}$ Fraunhofer Institute for Toxicology and Experimental Medicine, Center of Molecular Medicine and Medical Biotechnology, NikolaiFuchs-Str. 1, 30625 Hannover, Germany and ${ }^{2}$ Center of Pharmacology and Toxicology, Medical School of Hannover, Carl-Neuberg-Str. 1, 30625 Hannover, Germany

Email: Monika Niehof - niehof@item.fraunhofer.de; Jürgen Borlak* - juergen.borlak@item.fraunhofer.de

* Corresponding author

Published: 3 July 2009

BMC Molecular Biology 2009, 10:68 doi:10.1186/1471-2199-10-68

This article is available from: http://www.biomedcentral.com/147/-2199//0/68

(C) 2009 Niehof and Borlak; licensee BioMed Central Ltd.

This is an Open Access article distributed under the terms of the Creative Commons Attribution License (http://creativecommons.org/licenses/by/2.0), which permits unrestricted use, distribution, and reproduction in any medium, provided the original work is properly cited.
Received: I December 2008

Accepted: 3 July 2009

\begin{abstract}
Background: The choroid plexus consists of highly differentiated epithelium and functions as a barrier at the interface of the blood-cerebrospinal-fluid (CSF). This tissue may therefore determine the bioavailability and transport of drugs to the brain. Little is known about the expression of drug and xenobiotic metabolizing enzymes (DME) and of drug transporters in the human choroid plexus. Notably, the transcription factor and zinc finger protein HNF4alpha is a master regulator of DMEs and of drug transporters. As of today its activity in the blood-CSF barrier is unknown. Here we report our efforts in determining HNF4alpha activity in the regulation of $A B C$ transporters in the human and rat choroid plexus.
\end{abstract}

Results: We report expression of HNF4alpha by qRT-PCR and by immunohistochemistry and evidence transcript expression of the ATP-binding cassette transporters $A B C B I, A B C B 4, A B C C I$ 6 in choroid plexus. Additionally, HNF4alpha DNA binding activity at regulatory sequences of $A B C B 4$ and $A B C C I$ was determined by EMSA bandshift assays with a specific antibody. We then performed siRNA mediated functional knock down of HNF4alpha in Caco-2 cells and found $\mathrm{ABCCl}$ gene expression to be repressed in cell culture experiments.

Conclusion: Our study evidences activity of HNF4alpha in human and rat choroid plexus. This transcription factor targets DMEs and drug transporters and may well determine availability of drugs at the blood-CSF barrier.

\section{Background}

Drug delivery to the brain is mediated by several factors, most notably transport across the blood brain (BB) and the choroid plexus barrier; the latter displays drug-metabolizing enzyme and drug transport activity. It may therefore determine the overall cerebral bioavailability of drugs [1]. Specifically, the choroid plexus is located within brain vesicles. It is composed of a tight monolayer of polarized epithelial cells and forms the blood-cerebrospinal-fluid (CSF) barrier. Together with the blood-brain barrier, formed by endothelial cells of brain capillaries, it functions as the main interface between the central nervous system (CNS) and the peripheral circulation. Within the CNS this tissue is of great pharmacological interest, but 
information on the expression of efflux transporters such as the ATP binding cassette (ABC) proteins is missing [2]. In contrast, their expression in liver, kidney, and intestine has been studied in considerable detail [3-5]. Indeed, the $\mathrm{ABC}$ drug transporters extrude a variety of structurally diverse drugs, drug conjugates and metabolites in an active, ATP-dependent manner and even against high concentration gradients. The three main $\mathrm{ABC}$ families considered to be involved in the disposition of xenobiotics include the $\mathrm{ABCB}$ family (MDR subfamily, multidrug resistance, e.g. ABCB1/MDR1), the ABCC family of multidrug resistance proteins (MRP subfamily, multidrug resistance related proteins, e.g. $\mathrm{ABCC} 2 / \mathrm{MRP} 2)$, and the breast cancer resistance protein (ABCG2/BCRP) of the ABCG family $[3,4]$. However, comprehensive studies on the expression levels of ATP transporters in the human choroid plexus have not been attempted.

Notably, there is clear evidence for HNF4 $\alpha$ to play a role in the transcriptional control of drug transporters. Specifically, HNF $4 \alpha$ is a member of the nuclear receptor superfamily and one of the key players in liver biology [6-8]. Among the genes regulated by HNF $4 \alpha$ are a broad range of xenobiotic-metabolizing cytochrome P450 isozymes $[9,10]$, UDP-glucuronosyltransferases [11], sulfotransferases [12] and transporters including organic anion transporter $2[13]$, organic cation transporter $1[14]$, the ABC transporter ABCC2 [15], ABCC6 [16], ABCG5 [17] and ABCG8 [17]. Although there is clear evidence for HNF $4 \alpha$ to be of key importance in the control of drug metabolism it may also play a role in the regulation of transporters in the choroid plexus. Here we report our efforts in mapping HNF4 $\alpha$ to human and rat choroid plexus. We determined HNF $4 \alpha$ DNA binding activity and searched for transcript expression of various $A B C B$ and $A B C C$ transporters in the human choroid plexus. Apart from qRT-PCR and immunohistochemistry studies we evidence $A B C C 1$ gene expression to be highly dependent on HNF4 $\alpha$ as determined in functional knock down studies. Overall, we provide evidence for HNF4 $\alpha$ to be an important regulator of $\mathrm{ABC}$ drug transporters in the choroid plexus and thus may impact efficacy of pharmacotherapy targeted to the brain.

\section{Results}

Initially, we searched for $H N F 4 \alpha$ transcripts in individual samples of human and rat choroid plexus and confirmed gene expression of $H N F 4 \alpha$ by quantitative real time RTPCR (Figures 1A). We found HNF4 $\alpha$ transcript expression in human and rat choroid plexus to account for approximately a tenth of its expression in the liver (Figures 1A). It is of considerable importance that $H N F 4 \alpha$ expression in the human and rat choroid plexus is restricted to P1 promoter driven isoforms (Table 1). Furthermore, we studied expression of the insulin-like growth factor 2 (IGF2), tran-
Table I: HNF4 $\alpha$ isoform expression in human and rat choroid plexus.

\begin{tabular}{lll}
\hline Patient & HNF4 $\alpha \mathbf{P I}$ & HNF4 $\alpha \mathbf{P 2}$ \\
\hline $\begin{array}{l}\text { Patient 100-04 } \\
\text { patient 44-04 }\end{array}$ & 0.0342 & 0 \\
patient 62-04 & 0.0025 & 0 \\
\hline Animal & 0.4110 & 0 \\
\hline rat I & HNF4 $\alpha \mathbf{P I}$ & HNF4 $\alpha \mathbf{P 2}$ \\
rat 2 & 0.097 & 0 \\
rat 3 & 0.348 & 0 \\
\end{tabular}

$\mathrm{HNF} 4 \alpha \mathrm{PI}$ and $\mathrm{P} 2$ gene expression was measured in human and rat choroid plexus ( $n=3$, respectively) by real-time quantitative RT-PCR and computed relative to expression of mitATPase6, which served as a housekeeping gene. Patient characteristics are given in Table 5. Caco-2 cells and pancreatic tissue served as controls for HNF4oP2 expression in human and rats, respectively.

sthyretin (TTR) and the transcription factor FOXJ1 to further qualify choroidal epithelial cells of the brain $[18,19]$. These transcripts are specifically enriched in choroid plexus. We observed abundant expression of IGF2, TTR and FOXJ1 in human choroid plexus as compared to total brain RNA extracts (Figures 1B). There is the need to study histological well qualified tissue, as studies with total brain RNA extracts would render findings meaningless as will be discussed later on. Unfortunately, sufficient human choroid plexus tissue suitable for the harvest of nuclear protein and to perform western blotting as well as EMSA assay could not be obtained. We nonetheless demonstrate HNF4 $\alpha$ protein expression by immunohistochemistry by use of a specific HNF $4 \alpha$ antibody for human (Figures 2A) and rat choroid plexus (Figures 2C). To confirm specificity an excess of antigen preabsorbed to the antibody was used (Figures 2B, D).

We then analyzed expression of different members of the ABCB (MDR subfamily, multidrug resistance)/ABCC (MRP subfamily, multidrug resistance related) gene families in the human choroid plexus by quantitative real time RT-PCR and report results for $\mathrm{n}=3$ individual human choroid plexus samples. mRNA expression of ABCB4 (MDR2/3), ABCC1 (MRP1), ABCC2 (MRP2), ABCC3 (MRP3), ABCC4 (MRP4), ABCC5 (MRP5) and ABCC6 (MRP6) was comparable to its expression level in commercially available control total human brain RNA extracts (Figures 1C). mRNA expression of ABCB1 (MDR1) determined in choroidal epithelium was lower than in human liver $(\mathrm{n}=4)$ and in brain (Figures 1C).

We then searched for HNF4 $\alpha$ binding sites in proximal promoter sequences (up to -7000 bp) of drug transporter coding genes. For this purpose, we used two different bioinformatic approaches (see Material and Methods section 
A
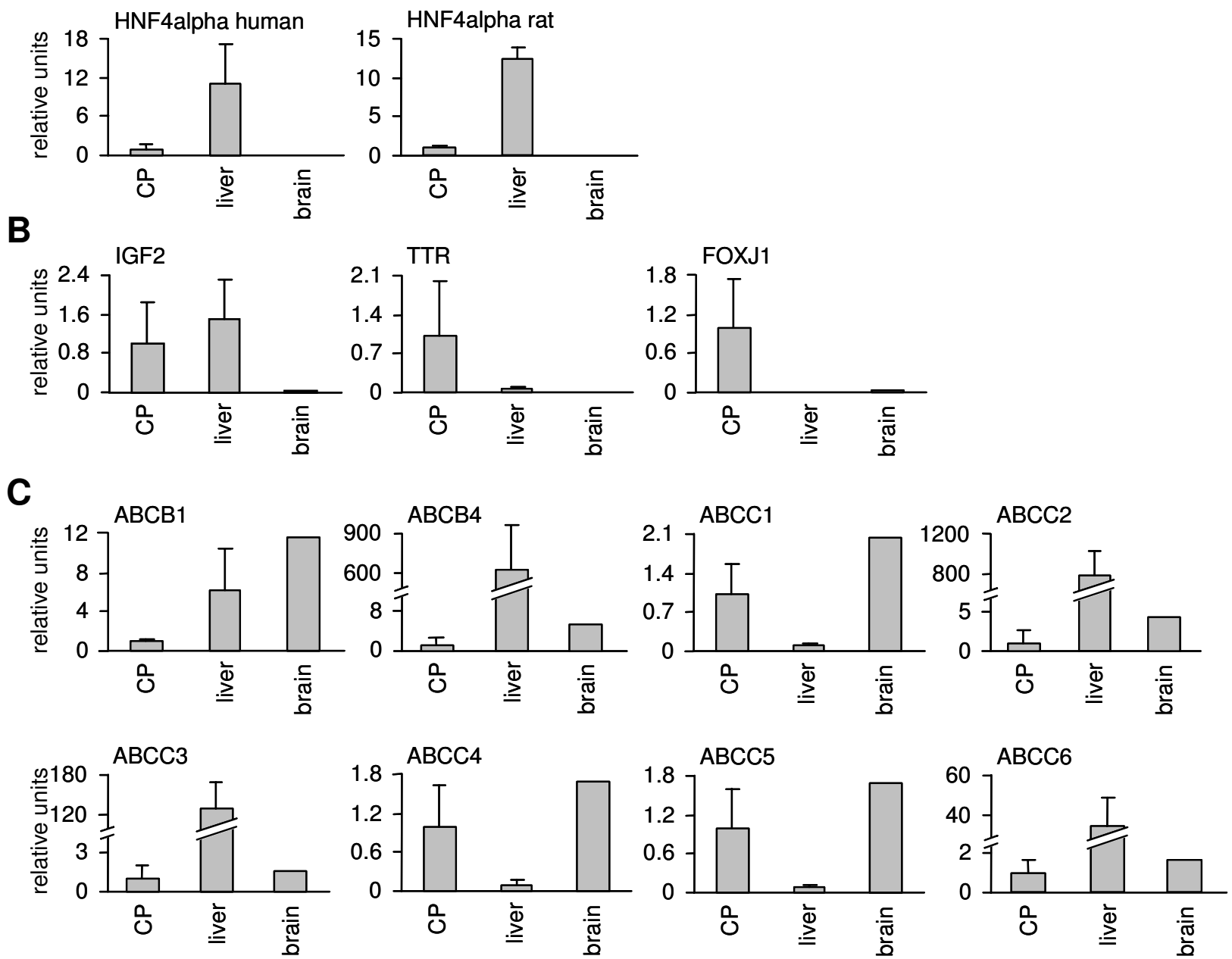

\section{Figure I}

Gene expression of HNF4 $\alpha$ and different ABC transporters in the choroid plexus. Gene expression of HNF4 $\alpha$ and different $A B C$ transporters in the choroid plexus. A: HNF4 $\alpha$ gene expression in human $(n=3)$ and rat choroid plexus $(n=3)$ was measured by quantitative real-time RT-PCR and determined relative to expression of mitATPase6, which served as a housekeeping gene. Expression levels were compared to liver and total brain. Mean values + SD are shown. B and C: Gene expression of FOXJI, IGF2 and TTR (B) and of different members of the ABCB and ABCC family (C) was analyzed in human choroid plexus by quantitative real-time RT-PCR and determined relative to expression of mitATPase6, which served as a housekeeping gene. Expression levels were compared to liver $(n=4)$ and total brain. Mean values + SD are shown.

for a description of the employed algorithms). We observed three binding sites within the ABCB4 promoter, spaced approximately by $600 \mathrm{bp}$ and $1600 \mathrm{bp}$ and two recognition sites within the $A B C C 1$ promoter (Table 2). Predicted binding sites were confirmed by EMSA band shift assays. We used 32P-labeled double-stranded DNA probes to specifically probe for $\mathrm{HNF} 4 \alpha$-sites located in the human ABCB4 (hABCB4_1, hABCB4_2 and hABCB4_3) and in the human $A B C C 1$ (hABCC1_1, hABCC1_2) gene. Note, DNA binding of nuclear extracts to the A-site of the $H N F 1 \alpha$-promoter (HNF1pro) served as a positive control.
This site is an established recognition site for HNF4 $\alpha$. Unfortunately, sufficient amount of human choroid plexus suitable for the isolation of nuclear protein could not be obtained. Instead, we used nuclear extracts isolated from the human intestinal cell line Caco-2 which expresses several $\mathrm{ABC}$ transporter genes [20] and therefore is a rich source of $\mathrm{HNF} 4 \alpha$ nuclear protein. Indeed, HNF $4 \alpha$ protein expression in Caco-2 cells is comparable to organs such as the liver [21]. As depicted in Figures 3A we observed strong binding of HNF4 $\alpha$ to the A-site of the HNF1 $\alpha$-promoter. We also observed strong binding of 

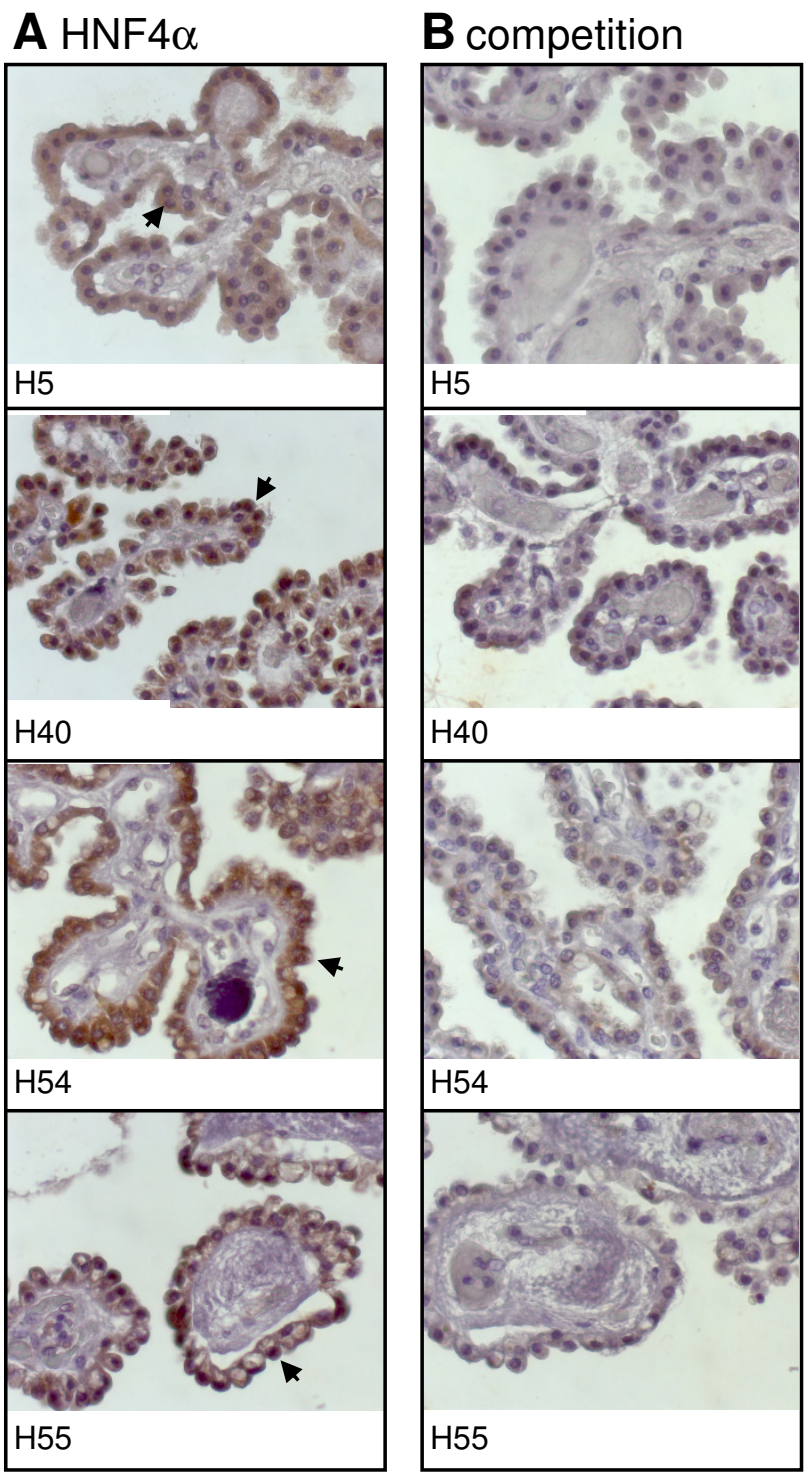

\section{HNF4 $\alpha$}

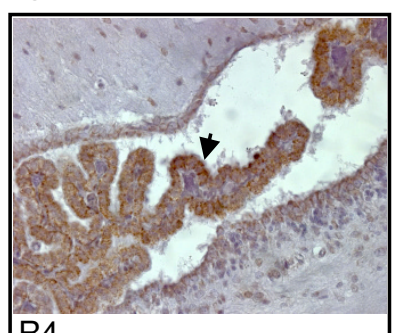

\section{R4}

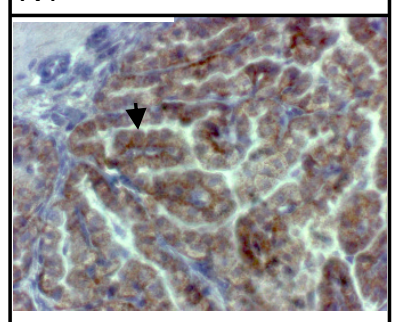

R8

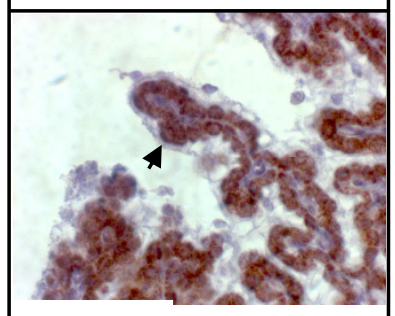

R11

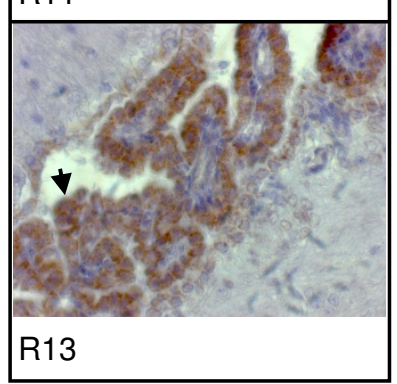

D competition

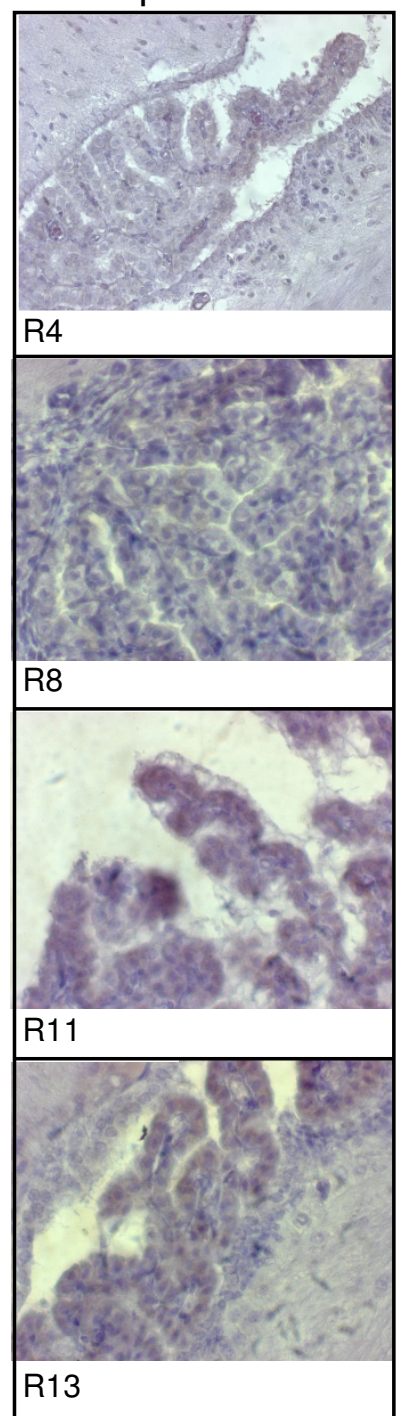

\section{Figure 2}

Immunohistochemical detection of HNF4 $\alpha$ in the choroid plexus. Slices of human (A, B) and rat (C, D) choroid plexus probes were stained with polyclonal antibodies against HNF4 $\alpha$. Arrows indicate representative $H N F 4 \alpha$ positive cells (A, C). To confirm specificity of the immunohistochemical localization antibodies were preabsorbed with excess of antigens for $\mathrm{HNF} 4 \alpha(B, D)$. Patient identification numbers were indicated respectively and patient characteristics are given in Table 5 . Magnification $\times 400$.

HNF4 $\alpha$ to the predicted sites in the promoters of $A B C B 4$ and $A B C C 1$ (Figures $3 \mathrm{~A}$ ); bands could be shifted with a specific HNF4 $\alpha$ antibody therefore demonstrating selectivity and specificity of the assay. Alignment of human, rat and mouse $A B C B 4$ and $A B C C 1$ genes did not identify common HNF4alpha binding sites. This points to differences in the molecular organization of $\mathrm{ABC}$ promoters in orthologous genes. HNF4alpha binding sites for the rat and mouse $A B C B 4$ and $A B C C 1$ genes are given in Table 2, whereas the sequences of oligonucleotides to confirm the predicted sites experimentally are shown in Table 3. As shown in Figures 3B and 3C EMSA band shift assays confirmed binding of HNF4 $\alpha$ to rat and mouse $A B C B 4$ and $A B C C 1$ targeted sequences.

To further probe for the role of HNF4 $\alpha$ in ABC gene regulation we employed an siRNA approach. Specifically, siRNA-mediated functional knock down of HNF4 $\alpha$ in the 
Table 2: Predicted binding sites for HNF4 $\alpha$ in ABC genes.

\begin{tabular}{|c|c|c|c|c|}
\hline Gene name & Accession number & bp relative to transcription start site & Score core/matrix & \\
\hline \multicolumn{5}{|l|}{ Human } \\
\hline \multirow[t]{5}{*}{$\mathrm{ABCB} 4$} & NM_000443.3 & -6274 to -6252 & V\$zemlin 13_II 045 & $1.000 / 0.896$ \\
\hline & & -4680 to -4658 & V\$HNF4_OI & $1.000 / 0.990$ \\
\hline & & & V\$zemlin 13_II 04 & $1.000 / 0.997$ \\
\hline & & -4063 to -4041 & V\$HNF4_OI & $1.000 / 0.954$ \\
\hline & & & V\$zemlin I3_II045 & $1.000 / 0.958$ \\
\hline \multirow[t]{3}{*}{$\mathrm{ABCCl}$} & NM_004996.3 & -1756 to -1734 & V\$HNF4_0I & $0.915 / 0.925$ \\
\hline & & -5266 to -5244 & V\$HNF4_0I & $1.000 / 0.944$ \\
\hline & & & V\$zemlin 13_II 045 & $1.000 / 0.969$ \\
\hline \multicolumn{5}{|l|}{ Rat } \\
\hline \multirow[t]{3}{*}{$\mathrm{ABCB} 4$} & NM_0I2690.I & -4584 to -4562 & V\$zemlin 13_II 045 & $1.000 / 0.894$ \\
\hline & & -39 to -17 & V\$HNF4_0I & $1.000 / 0.943$ \\
\hline & & & V\$zemlin 13_II045 & $1.000 / 0.978$ \\
\hline $\mathrm{ABCCl}$ & NM_02228I.2 & -2146 to -2124 & V\$HNF4_0I & $1.000 / 0.908$ \\
\hline \multicolumn{5}{|l|}{ Mouse } \\
\hline $\mathrm{ABCB} 4$ & NM_008830.2 & -5281 to -5259 & V\$zemlin 13_II 045 & $1.000 / 0.907$ \\
\hline \multirow[t]{2}{*}{$A B C C I$} & NM_008576.2 & +2626 to +2648 (Intron I) & V\$HNF4_OI & $1.000 / 0.924$ \\
\hline & & & V\$zemlin 13_II045 & $1.000 / 0.910$ \\
\hline
\end{tabular}

Transfac matrix (V\$HF4_0I) or self-generated matrix (V\$zemlin 13_II045) with a setting of core and matrix similarity 0.9 was used.

human Caco-2 cell line resulted in significantly decreased gene expression of ABCC1 (Table 4; for transfection efficiency and stable expression of mitATPase 6 after transfection see Niehof and Borlak, 2008 [22]). These results confirm ABCC1 to be a gene target of HNF4 $\alpha$. ABCB4 expression in Caco-2 cells is near the limit of detection. Consequently, knockdown experiments are not meaningful.

Table 3: Shift-probes sequences.

\section{Discussion}

Our study aimed for a better understanding of the role of HNF4 $\alpha$ in the regulation of drug transporters. Here we present evidence for expression of HNF $4 \alpha$ in the epithelium of the CSF barrier. By applying position weight matrices to genomic sequences of $\mathrm{ABC}$ transporters we were able to predict HNF $4 \alpha$ binding sites in the promoters of the $A B C B 4$ and $A B C C 1$ gene. The predicted binding sites were then confirmed by EMSA band shift assays. We propose a role for HNF $4 \alpha$ in the regulation of drug trans-

\begin{tabular}{|c|c|c|}
\hline Gene & Oligo name & Sequence \\
\hline \multicolumn{3}{|l|}{ Human } \\
\hline $\mathrm{HNFI} \alpha$ & HNFIpro & AGGGCTGA AGTCCA A AGTTCA GTCCCTTC \\
\hline \multirow[t]{3}{*}{$\mathrm{ABCB} 4$} & hABCB4_I (GS49) & AGAA AGGTCA A AGGCAA AGCA \\
\hline & hABCB4_2 (GS50) & GTGC AGGGCA A AGGTCA GATT \\
\hline & hABCB4_3 (GS5I) & GCTA AGTCCA A AGATCA ATTC \\
\hline \multirow[t]{2}{*}{$\mathrm{ABCCl}$} & hABCCI_I (GS48) & TTGAC AGTATA A AGGTCA AGCAA \\
\hline & hABCCI_2 (GSI7I) & 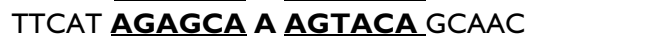 \\
\hline \multicolumn{3}{|l|}{ Rat } \\
\hline \multirow[t]{2}{*}{$\mathrm{ABCB} 4$} & rABCB4_I (GSI66) & AGAAG CCCTCA A AGTCCA CCTAT \\
\hline & rABCB4_2 (GSI67) & CGCAG CGAGCA A AGTCCA GGTCT \\
\hline $\mathrm{ABCCl}$ & rABCCI_I (GSI69) & GACAC GGGCCA A AGACCC ACAGA \\
\hline \multicolumn{3}{|l|}{ Mouse } \\
\hline $\mathrm{ABCB} 4$ & mABCB4_I (GSI68) & ATAGC CATGCA A AGTCCA AAAGA \\
\hline $\mathrm{ABCCl}$ & mABCCI_I (GSI70) & 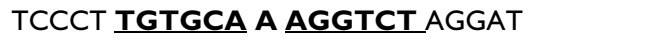 \\
\hline
\end{tabular}

The central five nucleotides of the HNF4 $\alpha$ binding site are highlighted in bold letters. The two direct repeats (DRI) separated by a spacer of one nucleotide are underlined. 


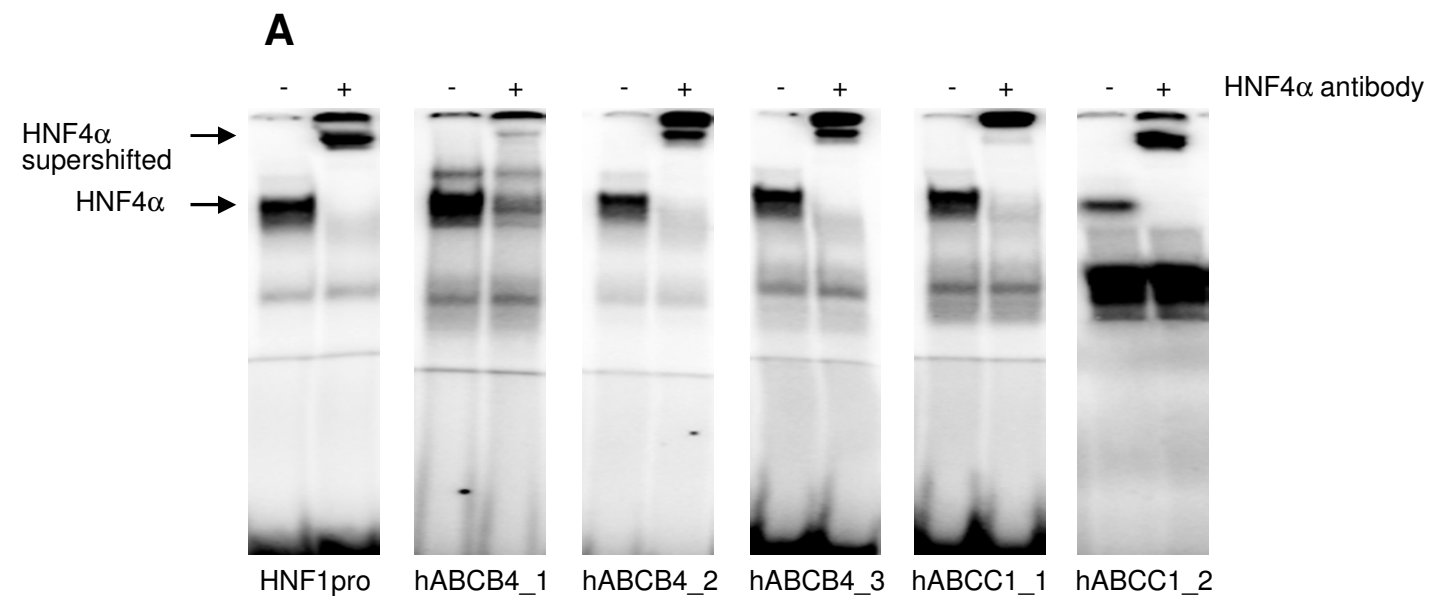

B

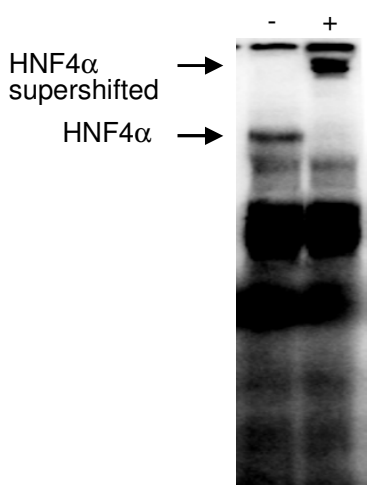

rABCB4_1

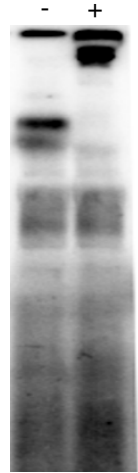

rABCB4 2

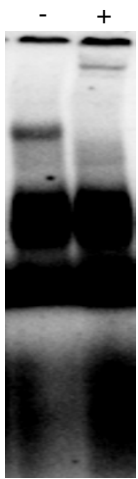

rABCC1_1
C
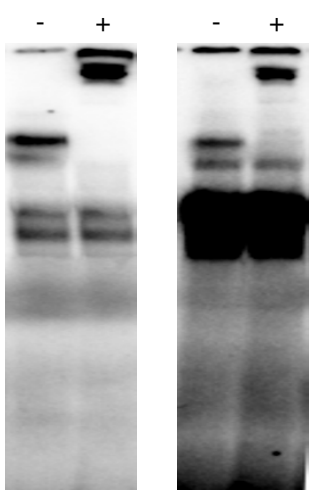

HNF $4 \alpha$ antibody

mABCB4_1 mABCC1_1

\section{Figure 3}

HNF4 $\alpha$ binding to promoters of ABCB4 and ABCCI. Electrophoretic mobility shift assays with $2,5 \mu \mathrm{g}$ Caco-2 cell nuclear extract and oligonucleotides corresponding to the A-site of the HNFI $\alpha$ promoter (HNFI pro) and to putative HNF4 $\alpha$ binding-sites within human (A), rat (B) and mouse (C) $A B C B 4$ and $A B C C I$ as 32 P labeled probe. In supershift assays an antibody directed against HNF4 $\alpha(+)$ was added. For oligonucleotide sequence information see Table 2 and 3.

Table 4: Functional knock down of HNF4 $\alpha$ in cultures of human Caco-2 cells.

\begin{tabular}{lll}
\hline Gene & Gene expression $48 \mathrm{~h}$ after HNF4 $\alpha$ siRNA transfection [\%] & p-value* \\
\hline HNF4 $\alpha$ & 24.0 & 0.0031 \\
\hline $\mathrm{ABCCl}$ & 56.4 & 0.0478 \\
\hline
\end{tabular}

Functional knock down of HNF4 $\alpha$ was already reported [22]. *A student's $t$ test was done to compare HNF4 $\alpha$ siRNA transfection against negative siRNA transfected controls. The results were considered significant when the $p$ value was less than 0.05 . Gene expression was determined by realtime quantitaive RT-PCR in triplicates; mitATPase6 served as housekeeping gene. The $\Delta \Delta \mathrm{C}_{\mathrm{T}}$-method was used to determine repression of gene expression. Values for HNF4 $\alpha$ siRNA transfection represent transcript abundance relative to negative siRNA transfected controls, which were set to $100 \%$. 
porters of the choroid plexus. Notably, HNF $4 \alpha$ is a key player in the regulation of genes coding for various metabolic pathways and of xenobiotic metabolism [6$9,23,24]$. This protein also promotes expression of an epithelial phenotype [25-27]. Specifically, epithelium of the choroid plexus cells is highly differentiated and functions as a blood-CSF barrier. The expression of HNF4 $\alpha$ in the epithelium of the choroid plexus and its DNA binding to regulatory sequences of drug transporters is a novel finding. Its expression accounts for approximately a tenth of HNF $4 \alpha$ expression found in liver. Furthermore, there is evidence for HNF4 $\alpha$ to undergo alternative splicing with isoforms may arising from alternative splicing and/or usage of two different promoters [6]. Specifically, the P1 promoter generates six different isoforms (HNF4 $\alpha 1-\alpha 6$ ); but activation of the P2 promoter results in isoforms HNF $4 \alpha 7-\alpha 9$. P2 promoter-driven HNF $4 \alpha$ isoforms are expressed throughout mouse liver development, but dis- appear after birth, while P1 promoter-driven transcripts are abundantly expressed postnataly [28]. Additionally, P2 isoforms are induced in mouse and human hepatocellular carcinoma $[29,30]$ and are primarily expressed in human pancreatic islets and exocrine cells [31]. In the case of the choroid plexus it appears that expression of HNF4 $\alpha$ is restricted to P1 promoter-driven isoforms. HNF4 $\alpha$ protein expression in human and rat choroid plexus could be clearly evidenced by immunohistochemistry. To further qualify tissue preparations of choroid plexus expression of IGF2, TTR and FOXJ1 was investigated; their expression are accepted genetic markers of the choroid plexus $[18,19]$. We validated tissue preparations by morphological and genetic markers. Unlike previous studies where expression of $H N F 4 \alpha$ transcripts could not be evidenced in total RNA extracts of the brain [6], we were able to confirm expression of $H N F 4 \alpha$ in the choroid plexus of human and rat brain. Most certainly, total brain RNA extracts

Table 5: Patient characteristics.

\begin{tabular}{|c|c|c|c|c|c|}
\hline Liver & & & & & \\
\hline Patient Identification & Sex & Age & Information & Tissue & Application \\
\hline P29 & $\mathrm{F}$ & 40 & Colorectal liver metastasis & $\begin{array}{l}\text { Healthy tissue from liver } \\
\text { resection }\end{array}$ & $\begin{array}{l}\text { Gene expression analysis, } \\
\text { comparison to choroid plexus }\end{array}$ \\
\hline P2 & $\mathrm{F}$ & 70 & Hepatocellular carcinoma & $\begin{array}{l}\text { Healthy tissue from liver } \\
\text { resection }\end{array}$ & $\begin{array}{l}\text { Gene expression analysis, } \\
\text { comparison to choroid plexus }\end{array}$ \\
\hline P3 & $\mathrm{F}$ & 57 & Hepatocellular carcinoma & $\begin{array}{l}\text { Healthy tissue from liver } \\
\text { resection }\end{array}$ & $\begin{array}{l}\text { Gene expression analysis, } \\
\text { comparison to choroid plexus }\end{array}$ \\
\hline P4 & M & 67 & Hepatocellular carcinoma & $\begin{array}{l}\text { Healthy tissue from liver } \\
\text { resection }\end{array}$ & $\begin{array}{l}\text { Gene expression analysis, } \\
\text { comparison to choroid plexus }\end{array}$ \\
\hline \multicolumn{6}{|l|}{ Choroid Plexus } \\
\hline Patient Identification & Sex & Age & Cause of death & Tissue & Application \\
\hline $44-04$ & $\mathrm{~F}$ & 63 & liver cirrhosis & $38 \mathrm{~h}$ post mortem & Gene expression analysis \\
\hline $62-04$ & $\mathrm{~F}$ & 79 & ovarial carcinoma & $33 \mathrm{~h}$ post mortem & Gene expression analysis \\
\hline $100-04$ & M & 74 & Acute myocardial infarction & $48 \mathrm{~h}$ post mortem & Gene expression analysis \\
\hline H5 & $M$ & 53 & Circulatory failure, liver cirrhosis & Choroid plexus & $\begin{array}{l}\text { Paraffin-embedded slices for } \\
\text { immunohistochemistry }\end{array}$ \\
\hline $\mathrm{H} 40$ & $M$ & 32 & Circulatory failure, endocarditis & Choroid plexus & $\begin{array}{l}\text { Paraffin-embedded slices for } \\
\text { immunohistochemistry }\end{array}$ \\
\hline $\mathrm{H} 54$ & M & 59 & $\begin{array}{l}\text { Respiratory insufficiency, } \\
\text { pneunomia }\end{array}$ & Choroid plexus & $\begin{array}{l}\text { Paraffin-embedded slices for } \\
\text { immunohistochemistry }\end{array}$ \\
\hline H55 & $M$ & 81 & $\begin{array}{l}\text { Circulatory failure, generalized } \\
\text { artheriosclerosis }\end{array}$ & Choroid plexus & $\begin{array}{l}\text { Paraffin-embedded slices for } \\
\text { immunohistochemistry }\end{array}$ \\
\hline
\end{tabular}


Table 6: Real-time PCR primer sequences and amplification settings.

\begin{tabular}{|c|c|c|c|c|c|c|c|c|}
\hline Gene & Accession number & Species & Primer sequence & Fragment length & Annealing & Extension & Fluorescence & Slope \\
\hline HNF4 $\alpha$ & NM_000457 & human & $\begin{array}{l}\text { fwd:CTGCTCGGAGCCACCAAGAGATCCATG } \\
\text { rev: ATCATCTGCCAGGTGATGCTCTGCA }\end{array}$ & $371 \mathrm{bp}$ & $60^{\circ} \mathrm{C}$ & $15 \mathrm{sec}$ & $88^{\circ} \mathrm{C}$ & -3.629 \\
\hline HNF4oPI & $\begin{array}{l}\text { NM_178849 } \\
\text { NM_178850 } \\
\text { NM_000457 }\end{array}$ & human & $\begin{array}{l}\text { fwd: GAATGCGACTCTCCAAAACC } \\
\text { rev: GGCACTGGTTCCTCTTGTCT }\end{array}$ & $339 \mathrm{bp}$ & $68^{\circ} \mathrm{C}$ & $14 \mathrm{sec}$ & $88^{\circ} \mathrm{C}$ & -3.058 \\
\hline HNF4oP2 & NM_00I030003 & human & $\begin{array}{l}\text { fwd: GGGCTCCAGTGGAGAGTTC } \\
\text { rev: CATAGCTTGACCTTCGAGTGC }\end{array}$ & 342 bp & $68^{\circ} \mathrm{C}$ & $14 \mathrm{sec}$ & $88^{\circ} \mathrm{C}$ & -2.648 \\
\hline FOXJI & NM_00I454 & human & $\begin{array}{l}\text { fwd: CTACTCGTATGCCACGCTCA } \\
\text { rev: CGAGGCACTTTGATGAAGC }\end{array}$ & $183 \mathrm{bp}$ & $60^{\circ} \mathrm{C}$ & $8 \mathrm{sec}$ & $86^{\circ} \mathrm{C}$ & -3.459 \\
\hline IGF2 & NM_000I62 & human & $\begin{array}{l}\text { fwd: GGTGCTTCTCACCTTCTTGG } \\
\text { rev: GGGGTATCTGGGGAAGTTGT }\end{array}$ & $298 \mathrm{bp}$ & $68^{\circ} \mathrm{C}$ & $12 \mathrm{sec}$ & $90^{\circ} \mathrm{C}$ & -2.724 \\
\hline TTR & NM_00037I & human & $\begin{array}{l}\text { fwd: CAGAAAGGCTGCTGATGACA } \\
\text { rev: GCCGTGGTGGAATAGGAGTA }\end{array}$ & $261 \mathrm{bp}$ & $60^{\circ} \mathrm{C}$ & II sec & $86^{\circ} \mathrm{C}$ & -3.438 \\
\hline$A B C B I$ & NM_000927 & human & $\begin{array}{l}\text { fwd: AAAAAGATCAACTCGTAGGAGTG } \\
\text { rev: GCACAAAATACACCAACAA }\end{array}$ & $161 \mathrm{bp}$ & $60^{\circ} \mathrm{C}$ & $7 \mathrm{sec}$ & $81^{\circ} \mathrm{C}$ & -3.331 \\
\hline $\mathrm{ABCB} 4$ & NM_000443 & human & $\begin{array}{l}\text { fwd: CCACAGCGAACTGATGAAGA } \\
\text { rev: CACGACAAAGTAGGGCCATT }\end{array}$ & $301 \mathrm{bp}$ & $68^{\circ} \mathrm{C}$ & $13 \mathrm{sec}$ & $83^{\circ} \mathrm{C}$ & -3.826 \\
\hline $\mathrm{ABCCl}$ & NM_004996 & human & $\begin{array}{l}\text { fwd: AGTCCCCACAGAAGGAGTGG } \\
\text { rev: TCCCCGACCGTGGAGGATTT }\end{array}$ & 358 bp & $60^{\circ} \mathrm{C}$ & $15 \mathrm{sec}$ & $87^{\circ} \mathrm{C}$ & -3.639 \\
\hline$A B C C 2$ & NM_000392 & human & $\begin{array}{l}\text { fwd: CCGTATCAGGTTTGCCAGTT } \\
\text { rev: CAACAGCCACAATGTTGGTC }\end{array}$ & $312 \mathrm{bp}$ & $60^{\circ} \mathrm{C}$ & $13 \mathrm{sec}$ & $84^{\circ} \mathrm{C}$ & -3.756 \\
\hline
\end{tabular}


Table 6: Real-time PCR primer sequences and amplification settings. (Continued)

\begin{tabular}{|c|c|c|c|c|c|c|c|c|}
\hline$\overline{A B C C 3}$ & NM_003786 & human & $\begin{array}{l}\text { fwd: CTCAATGTGGCAGACATCGG } \\
\text { rev: GGGAGCTCACAAACGTGTGC }\end{array}$ & 177 bp & $60^{\circ} \mathrm{C}$ & $8 \mathrm{sec}$ & $87^{\circ} \mathrm{C}$ & -3.731 \\
\hline $\mathrm{ABCC} 4$ & $\begin{array}{l}\text { NM_005845 } \\
\text { NM_0011055I5 }\end{array}$ & human & $\begin{array}{l}\text { fwd CTTGGAGAGGAGTTGCAAGG } \\
\text { rev: GCTGTGTTCAAAGCCACAGA }\end{array}$ & $236 \mathrm{bp}$ & $68^{\circ} \mathrm{C}$ & $10 \mathrm{sec}$ & $78^{\circ} \mathrm{C}$ & -4.479 \\
\hline$A B C C 5$ & NM_005688 & human & $\begin{array}{l}\text { fwd: CCTGTTTGGGAAGGAATATGA } \\
\text { rev: CCTGTTTGGGAAGGAATATGA }\end{array}$ & $203 \mathrm{bp}$ & $60^{\circ} \mathrm{C}$ & $9 \mathrm{sec}$ & $88^{\circ} \mathrm{C}$ & -3.446 \\
\hline $\mathrm{ABCC} 6$ & NM_00II7I & human & $\begin{array}{l}\text { fwd: TTCTCTGTGTCGCTGGTGTC } \\
\text { rev: GGCACTGTGTATGGTGATGC }\end{array}$ & $309 \mathrm{bp}$ & $60^{\circ} \mathrm{C}$ & $13 \mathrm{sec}$ & $87^{\circ} \mathrm{C}$ & -2.982 \\
\hline MitATPase6 & NC_00I807 & human & $\begin{array}{l}\text { fwd: CTAAAGGACGAACCTGA } \\
\text { rev: TGGCCTGCAGTAATGTT }\end{array}$ & $315 \mathrm{bp}$ & $55^{\circ} \mathrm{C}$ & $13 \mathrm{sec}$ & $83^{\circ} \mathrm{C}$ & -3.608 \\
\hline HNF4 $\alpha$ & NM_022I80 & rat & $\begin{array}{l}\text { fwd: GCCTGCCTCAAAGCCATCAT } \\
\text { rev: GACCCTCCAAGCAGCATCTC }\end{array}$ & 274 bp & $55^{\circ} \mathrm{C}$ & II sec & $88^{\circ} \mathrm{C}$ & -3.697 \\
\hline HNF4 $\alpha \mathrm{PI}$ & DI0554, EFI93392 & rat & $\begin{array}{l}\text { fwd: AAATGTGCAGGTGTTGACCA } \\
\text { rev: CACGCTCCTCCTGAAGAATC }\end{array}$ & $178 \mathrm{bp}$ & $60^{\circ} \mathrm{C}$ & $7 \mathrm{sec}$ & $87^{\circ} \mathrm{C}$ & -3.296 \\
\hline HNF4 $\alpha$ P2 & $\begin{array}{l}\text { AF329936 } \\
\text { EFI93390 }\end{array}$ & rat & $\begin{array}{l}\text { fwd: CTCCAGTGGCGAGTCCTTAT } \\
\text { rev: TCACGCTCCTCCTGAAGAAT }\end{array}$ & $17 \mid \mathrm{bp}$ & $60^{\circ} \mathrm{C}$ & $7 \mathrm{sec}$ & $87^{\circ} \mathrm{C}$ & -2.273 \\
\hline MitATPase6 & NC_00I665 & rat & $\begin{array}{l}\text { fwd: CTAAAGGACGAACCTGA } \\
\text { rev: TGGCCTGCAGTAATGTT }\end{array}$ & $315 \mathrm{bp}$ & $55^{\circ} \mathrm{C}$ & $13 \mathrm{sec}$ & $83^{\circ} \mathrm{C}$ & -3.644 \\
\hline
\end{tabular}


dilute copy number of $H N F 4 \alpha$ transcripts to presumable levels below the limit of detection. Here, we evidence binding of HNF $4 \alpha$ to regulatory sequences of drug transporters expressed in the choroid plexus and analyzed gene expression of $\mathrm{ABC}$ transporters in patients with different causes of death, but the functional significance of the newly identified HNF4 $\alpha$ binding sites in activating the ABCB4 and ABCC1 promoters still needs to be established.

In the past attempts to detect HNF4 $\alpha$ DNA binding in a choroid plexus papilloma failed [32]. The investigators performed EMSA experiments with nuclear extracts of rat liver, kidney and intestine and of SV40-induced choroid plexus papilloma of transgenic mice, but unfortunately probed for HNF4alpha binding with an oligonucleotide corresponding to the HNF4 $\alpha$ binding site in the mouse TTR (transthyretin) promoter. The authors did not employ an antibody in EMSA band shift assays; instead, competition with excess of unlabeled probes was done. Although the authors described a weak binding of HNF $4 \alpha$ with nuclear extracts from kidney they considered intestine as well as choroid plexus as deficient for HNF4 $\alpha$ binding. There is a need to consider tissue specific DNA binding activity. HNF4 $\alpha$ binding at the TTR promoter is much less as compared to the A-site in the HNF1 promoter (not exceeding a tenth, data not shown). As detailed above, HNF4 $\alpha$ gene expression in human and rat choroid plexus is approximately one tenth of its expression in the liver (see Figures 1A). It is therefore not surprising that previous investigators [32] failed to detect HNF4 $\alpha$ protein in intestine and choroid plexus, even though the authors described weak expression of this protein in kidney. By now, it is well established that HNF4 $\alpha$ expression is not restricted to liver, but also functions in kidney and intestine $[33,34]$. Here we evidence by immunohistochemical staining HNF4 $\alpha$ to be expressed in epithelium of human and rat choroid plexus (see Figures 2).

Notably, the choroid plexus functions as a barrier for drug uptake to the brain. This tissue expresses drug metabolizing enzymes (DMEs) and some transporters [1]. Expression of DMEs in the choroid plexus is part of a defense program to prevent entry of xenobiotics into the brain. The blood-CSF barrier also regulates entry and distribution of various pharmacologically active compounds between the blood and the CSF interface and is basically involved in numerous exchange processes thereby determining the supply of the brain with nutrients and hormones [1]. Indeed, endogenous metabolites, as well as neurotransmitter and metabolites from the brain are cleared via this barrier [19]. In drug therapies efflux transporters of the ABC-family are of pivotal importance in determining therapeutic tissue levels. In the past research focused on their regulation in liver, kidney and intestine $[3,4]$. The knowledge on drug transporter in specialized tissues of the brain is incomplete. Specifically, $\mathrm{ABCB}$ (MDR) proteins accept a broad range of substrates and may transport large lipophilic, neutral or cationic compounds. This includes a vast number of neuropharmacological drugs such as antiepileptic and antiviral drugs, antidepressants, opiods, antipsychotics and tranquilizer [35-40]. ABCB1, a transporter with highest expression in the gastrointestinal tract $[4,41]$, is expressed at low levels in human choroid plexus, that is much lower than in liver and total brain. Our findings are consistent with results reported previously for rats [42]. Its apical expression in rat, mouse and human choroidal epithelium was shown previously [43]. Furthermore, ABCB4 is highly expressed in the liver, where it is acting as a "flippase" in transporting phospholipids into the bile, but $\mathrm{ABCB} 4$ can also bind and transport a subset of $A B C B 1$ substrates with an overlap in substrate specificity [44]. As reported for $A B C B 1$, $A B C B 4$ is expressed at low levels in human choroid plexus, i.e. more than 500 fold lower than in liver. Low $A B C B 4$ expression was also evidenced in choroidal epithelium of the rat [42], but to the best of our knowledge our study is the first report on expression in human choroid plexus. An apical distribution of ABCB1 in neonatal cultured rat choroid plexus cells imply a drug transport from blood into CSF [43]. In endothelial cells of small blood capillaries of the blood-brain barrier, apical located ABCB1 pumps drugs back into the blood stream and therefore limits drug penetration to the brain [2].

Likewise, the ABCC (MRP) proteins are multispecific organic anion transporters and accept glucurono-, glutathione- and sulfo-conjugates. They transport physiological substrate conjugates as well as drug conjugates. Expression of $A B C C 1-6$ mRNA transcripts was reported for rat choroid plexus [42] as was expression of $A B C C 1$ for human choroid plexus $[43,45,46]$. ABCC1, ABCC4 and $A B C C 5$ were expressed in human choroid plexus at least at 10 fold higher than in liver; whereas $A B C C 2, A B C C 3$ and $A B C C 6$ were expressed up to 800 fold lower than liver. Similar results were reported for $A B C C$ transporter expression in rat choroid plexus [42]. Notably, ABCC1 is localized at the basolateral membrane of choroid plexus $[43,45,46]$, but Gazzin et al [46] described a major difference in the localization of ABCB1 and ABCC1 proteins between the blood-brain and the blood-CSF barrier with strongest expression of $\mathrm{ABCC} 1$ at the choroidal epithelium. Indeed, ABCC proteins contribute to the protective role of the choroid plexus and mediate basolateral efflux of conjugates resulting from choroidal drug metabolism into the blood. Although it is known that the choroid plexus is important in regulating the distribution of various pharmacologically active compounds between the blood and the CSF, the characterization of the involved human $\mathrm{ABC}$ transporters gives new insights into the function of the CSF barrier. 
Furthermore, ABCBs (MDRs) and ABCCs (MRPs) are inducible transporters and are highly responsive to chemotherapeutics, carcinogens, inflammation, heat shock, hypoxia and irradiation [47]. They are regulated by a complex network of transcriptional cascades, such as by multiple ligand activated nuclear receptors like retinoid $\mathrm{X}$ receptor (RXR), farnesoid X receptor (FXR), constitutive androstane receptor (CAR) and the xenobiotic receptor pregnane $\mathrm{X}$ receptor (PXR) $[47,48]$. There is also evidence for the transcription factors AP-1, p53, Egr-1 and WT-1 to participate in their regulation with NF-Y, Sp1 and Sp3 being involved in the constitutive expression [47]. Recently, an upregulation of $A B C B 1, A B C B 4$ and $A B C C 4$ transcripts was reported in human embryonic kidney cells that conditionally expressed wild-type HNF4 $\alpha$ [33]. An important role of $\mathrm{HNF} 4 \alpha$ in the transcriptional control of drug transporters was reported for human hepatocytes as determined by adenoviral HNF4 $\alpha$-siRNA mediated knockdown [49]. We also employed an siRNA mediated functional knockdown of HNF4 $\alpha$ and found ABCC1 gene expression to be massively repressed. There is a need to improve an understanding of the mechanism by which transporters are regulated. This will impact the design of novel CNS therapeutics. Targeting transporters may thus be useful in achieving therapeutic tissue levels of CNS drugs.

\section{Conclusion}

We report expression of HNF4 $\alpha$ in choroid plexus of the human and rat brain. This factor might regulate expression of some ATP binding cassette transporters. Targeting of HNF $4 \alpha$ may impact efficacy of pharmacotherapy of CNS drugs.

\section{Methods \\ Human and rat tissue}

A total of $\mathrm{n}=7$ human and $\mathrm{n}=7$ rat tissues were analyzed. Samples of human choroid plexus $(n=3$, gene expression analysis) were kindly provided by T. Arendt (Department of Neuroanatomy, Paul-Flechsig-Institute, University of Leipzig, Germany). Paraffin-embedded slices of human choroid plexus for immunohistochemistry $(n=4)$ were kindly provided by C. Grothe (Institute of Neuroanatomy, Hannover Medical School, Hannover, Germany). Human liver tissue (gene expression analysis) was obtained from patients undergoing hepatic resections and were kindly provided by J. Klempnauer (Department of Visceral and Transplantation Surgery, Hannover Medical School, Hannover, Germany). Patient characteristics are given in Table 5. Control human brain RNA was purchased from BD Biosciences (Heidelberg, Germany).

Samples of rat choroid plexus ( $\mathrm{n}=3$, Sprague Dawley rats, gene expression analysis) were kindly provided by $\mathrm{H}$. Hilbig and K. Spanel-Borowski (Department of Anatomy,
University of Leipzig, Germany). Samples of rat liver and brain (Sprague Dawley rats, gene expression analysis) were generated in-house. Paraffin-embedded slices of rat brain (Sprague Dawley rats) containing choroid plexus regions for immunohistochemistry $(n=4)$ were kindly provided by C. Grothe (Institute of Neuroanatomy, Hannover Medical School, Hannover, Germany).

\section{Quantitative real-time RT-PCR}

Analysis of human samples: Three human choroid plexus samples and four human liver samples were analyzed separately and used for calculation of the mean and standard deviation. Analysis of rat samples: Three rat choroid plexus samples, three rat liver and three rat brain samples were analyzed separately and used for calculation of the mean and standard deviation. Total RNA from choroid plexus and liver was isolated using the RNeasy Mini Kit (Qiagen, Hilden, Germany) according to the manufacturers recommendations. Subsequently to RNA isolation, a DNase I digest was performed. $4 \mu \mathrm{g}$ total RNA from each sample was used for reverse transcription (Omniscript Reverse Transcriptase, Qiagen, Hilden, Germany). Quantitative real-time RT-PCR measurement was done with the Lightcycler (Roche Diagnostics, Mannheim, Germany) with the following conditions: denaturation at $95^{\circ} \mathrm{C}$, annealing at different temperatures for $8 \mathrm{sec}$, extension at $72^{\circ} \mathrm{C}$ for different times and detection of SYBR-Green Ifluorescence at different temperatures. Detailed primer specific conditions and oligonucleotide sequence information are given in Table 6 . Relative quantification was performed using the "Fit Points Method" of the LightCycler3 Data Analysis Software version 3.5.28 (Roche Diagnostics, Mannheim, Germany) by comparing the sample values to a standard curve within the linear range of amplification. This comparison was performed during each LightCycler Run (for genes of interest as well as for the housekeeping gene, i.e. mitATPase6). The standardized sample values for each gene of interest were divided by the standardized values of the housekeeping gene. The slope of external standard curves are given in Table 6, indicating the PCR efficiency for each amplicon.

\section{Caco-2 cell culture}

Caco- 2 cells are a valuable source for HNF4 $\alpha$ nuclear protein [21] and were obtained from and cultivated as recommended by DSMZ (Deutsche Sammlung von Mikroorganismen und Zellkulturen $\mathrm{GmbH}$, Braunschweig, Germany) and seeded with a density of $4 \times 10^{6}$ cells per $75 \mathrm{~cm}^{2}$ flask and harvested after 11 days of culture.

\section{Isolation of nuclear extracts}

Nuclear extracts from Caco-2 cells were isolated by the modified method of Dignam et al [50]. Eleven days after seeding cells were washed twice with ice-cold PBS, scraped into microcentrifuge tubes and centrifuged for $5 \mathrm{~min}$ at 
$2000 \times \mathrm{g}, 4^{\circ} \mathrm{C}$. Cell pellets were resuspended in lysis buffer $\left(10 \mathrm{mM}\right.$ Tris pH 7.4, $2 \mathrm{mM} \mathrm{MgCl}_{2}, 140 \mathrm{mM} \mathrm{NaCl}$, $1 \mathrm{mM}$ DTT, $4 \mathrm{mM}$ Pefabloc, 1\% Aprotinin, $40 \mathrm{mM} \beta$-glycerophosphate, $1 \mathrm{mM}$ sodiumorthovanadate and $0.5 \%$ TX100) at $4{ }^{\circ} \mathrm{C}$ for $10 \mathrm{~min}\left(300 \mu \mathrm{l}\right.$ for $1 \times 10^{7}$ cells $)$, transferred onto one volume of $50 \%$ sucrose in lysis buffer and centrifuged at $14000 \times \mathrm{g}$ and $4{ }^{\circ} \mathrm{C}$ for $10 \mathrm{~min}$. Nuclei were resuspended in Dignam C buffer (20 mM Hepes pH 7.9, $25 \%$ glycerol, $420 \mathrm{mM} \mathrm{NaCl}, 1.5 \mathrm{mM} \mathrm{MgCl}_{2}, 0.2 \mathrm{mM}$ EDTA, $1 \mathrm{mM}$ DTT, $4 \mathrm{mM}$ Pefabloc, $1 \%$ Aprotinin, $40 \mathrm{mM}$ $\beta$-glycerophosphate, $1 \mathrm{mM}$ sodiumorthovanadate, $30 \mu \mathrm{l}$ for $1 \times 10^{7}$ cells) and gently shaked at $4^{\circ} \mathrm{C}$ for $30 \mathrm{~min}$. Nuclear debris was removed by centrifugation at $14000 \times$ $\mathrm{g}$ at $4^{\circ} \mathrm{C}$ for $10 \mathrm{~min}$. Protein concentrations were determined according to the method of Smith et al [51]. The extracts were aliquoted and stored at $-70^{\circ} \mathrm{C}$.

\section{Electrophoretic mobility shift assays}

Forward and reverse oligonucleotides (for sequence information see Table 3) were purchased from MWG Biotech (Ebersberg/Muenchen, Germany), annealed and 32Plabeled using ${ }^{32} \mathrm{P} \gamma \mathrm{ATP}$ and T4-kinase (New England Biolabs, Frankfurt, Germany). 2,5 $\mu$ g Caco-2 cell nuclear extract and $10^{5} \mathrm{cpm}(0.027 \mathrm{ng})$ radiolabeled probe were incubated in binding buffer consisted of $25 \mathrm{mM}$ HEPES, pH 7.6, $5 \mathrm{mM} \mathrm{MgCl}_{2}, 34 \mathrm{mM} \mathrm{KCl}, 2 \mathrm{mM}$ DTT, $2 \mathrm{mM}$ Pefabloc, $2 \%$ Aprotinin, $40 \mathrm{ng}$ of poly (dI-dC)/ $\mu \mathrm{l}$ and $100 \mathrm{ng}$ of bovine serum albumin/ $\mu \mathrm{l}$ for 20 minutes on ice. Free DNA and DNA-protein complexes were resolved on a $6 \%$ polyacrylamide gel (acrylamide: bisacrylamide ratio $=$ 37.5:1). Super shift experiments were done with a $1 \mu \mathrm{g}$ HNF4 $\alpha$ specific antibody (sc-6556x, Santa Cruz Biotechnology, Heidelberg, Germany). DNA binding of nuclear extracts to the A-site of the HNF1 $\alpha$-promoter (HNF1pro) served as a positive control.

\section{Bioinformatic searches for HNF4 $\alpha$ binding-sites}

The transcription start site (TSS, +1 ) of the NCBI mRNA reference sequence (RefSeq) was aligned using the UCSC Genome Browser http://genome.ucsc.edu/ for promoter annotation of the respective genes. Proximal promoters (up to $-7000 \mathrm{bp}$ ) of human $\mathrm{ABCB} 1, \mathrm{ABCB} 4$ and $\mathrm{ABCC} 1$ to ABCC6 were checked for putative HNF4 $\alpha$ binding-sites with the tool MATCH [52], http://www.biobase.de by employing two different weight matrix, i.e. V\$HNF4_01, Transfac matrix (generated by Biobase) and V\$zemlin1311045 (self-generated). V\$zemlin13-11045 is based on a collection of 33 well known HNF4 $\alpha$ sites and was generated using the matrix generation tool of Biobase http:// www.biobase.de. At least one of both matrices has to exceed the cut-off of 0.9 for core similarity and 0.9 for matrix similarity (Table 2). Furthermore, proximal promoters (up to $-7000 \mathrm{bp}$ ) of rat and mouse ABCB4 and $\mathrm{ABCC} 1$ were checked for putative $\mathrm{HNF} 4 \alpha$ binding sites (Table 2).

\section{Immunohistochemistry}

The sections were deparaffinized, demasked by heating, incubated with $0,6 \% \mathrm{H}_{2} \mathrm{O}_{2}$ in methanol for $30 \mathrm{~min}$, and subsequently with protein block serum-free reagent (Dako, Glostrup, Denmark) for $10 \mathrm{~min}$. Incubation with polyclonal antibody (Santa Cruz Biotechnology, Heidelberg, Germany) against HNF4 $\alpha$ (sc-6556x, 1:400 dilution for rat sections, 1:200 dilution for human sections) was performed for $45 \mathrm{~min}$. The sections were rinsed with Trisbuffered saline, incubated with biotinylated universal secondary antibodies (Dako, Glostrup, Denmark) for $15 \mathrm{~min}$ and subsequently with horseradish peroxidase-conjugated streptavidin solution (Dako, Glostrup, Denmark) for $15 \mathrm{~min}$. Labeling was detected using a diaminobenzidine (DAB) chromogen solution (Dako, Glostrup, Denmark) for $5 \mathrm{~min}$. The sections were counterstained with hematoxylin before examination under light microscope. To confirm the specificity of the immunohistochemical localization, antibodies preabsorbed $2 \mathrm{~h}$ with a twenty fold excess of antigen for HNF4 $\alpha$ (sc-6556P, Santa Cruz Biotechnology, Heidelberg, Germany) were used.

\section{siRNA silencing of $H N F 4 \alpha$}

Human HNF4 $\alpha$-specific siRNA probes were purchased from Qiagen (Hilden, Germany). Caco-2 cells $\left(1,5 \times 10^{5}\right.$ cells/well in 24-well plate) were transfected in triplicate for $48 \mathrm{~h}$ with $25 \mathrm{nM}$ of the siRNA duplex using HiPerFect transfection reagent (Qiagen, Hilden, Germany). AlexaFluor488 labeld siRNA (Qiagen, Hilden Germany) was used as negative siRNA and as positive control for transfection efficiency. For transfection efficiency and stable expression of mitATPase 6 after transfection see Niehof and Borlak, 2008 [22].

\section{Abbreviations}

ABC transporter: ATP-binding cassette transporter; CSF: cerebrospinal fluid; DME: drug metabolizing enzymes; EMSA: electrophoretic mobility shift assay; HNF: hepatocyte nuclear factor; MDR: multidrug resistance gene family (ABCB); MRP: multidrug resistance related proteins gene family (ABCC); TTR: transthyretin.

\section{Authors' contributions}

JB designed the entire study, supervised the experimental works and is responsible for the final writing of the manuscript, MN supervised the experiments and prepared the initial draft of the manuscript. Both authors read and approved the final manuscript.

\section{Acknowledgements}

We thank S. Marschke, A. Pfanne and A. Schulmeyer for valuable technical assistance, S. Reymann and R. Zemlin for assistance in bioinformatics and advice on design of PCR primers, T. Arendt, U. Gärtner and C. Grothe for providing samples of human choroid plexus and H. Hilbig, K. SpanelBorowski and $\mathrm{C}$. Grothe for the preparation of rat choroid plexus. This 
work was supported by a grant of the Lower Saxony Ministry of Culture and Science to J.B.

\section{References}

I. Ghersi-Egea JF, Strazielle N: Brain drug delivery, drug metabolism, and multidrug resistance at the choroid plexus. Microsc Res Tech 2001, 52:83-88.

2. Graff CL, Pollack GM: Drug transport at the blood-brain barrier and the choroid plexus. Curr Drug Metab 2004, 5:95-108.

3. Schinkel $\mathrm{AH}$, Jonker JW: Mammalian drug efflux transporters of the ATP binding cassette (ABC) family: an overview. Adv Drug Deliv Rev 2003, 55:3-29.

4. Glavinas H, Krajcsi P, Cserepes J, Sarkadi B: The role of ABC transporters in drug resistance, metabolism and toxicity. Curr Drug Deliv 2004, I:27-42.

5. Toyoda Y, Hagiya Y, Adachi T, Hoshijima K, Kuo MT, Ishikawa T: MRP class of human ATP binding cassette (ABC) transporters: historical background and new research directions. Xenobiotica 2008, 38:833-862

6. Sladek FM, Seidel SD: Hepatocyte nuclear factor 4alpha. In Nuclear Receptors and Disease Edited by: Burris T, McCabe ERB. Academic Press, London; 2001:309-36I.

7. Schrem H, Klempnauer J, Borlak J: Liver-enriched transcription factors in liver function and development. Part I: the hepatocyte nuclear factor network and liver-specific gene expression. Pharmacol Rev 2002, 54:|29-|58.

8. Parviz F, Matullo C, Garrison WD, Savatski L, Adamson JW, Ning G et al: Hepatocyte nuclear factor 4alpha controls the development of a hepatic epithelium and liver morphogenesis. Nat Genet 2003, 34:292-296.

9. Jover R, Bort R, Gomez-Lechon MJ, Castell JV: Cytochrome P450 regulation by hepatocyte nuclear factor 4 in human hepatocytes: a study using adenovirus-mediated antisense targeting. Hepatology 2001, 33:668-675.

10. Gonzalez F]: Regulation of hepatocyte nuclear factor 4 alphamediated transcription. Drug Metab Pharmacokinet 2008, 23:2-7.

II. Barbier O, Girard H, Inoue Y, Duez H, Villeneuve L, Kamiya A, et al.: Hepatic expression of the UGTIA9 gene is governed by hepatocyte nuclear factor 4alpha. Mol Pharmacol 2005, 67:24I-249.

12. Echchgadda I, Song CS, Oh T, Ahmed M, De LCl, Chatterjee B: The xenobiotic-sensing nuclear receptors pregnane $X$ receptor, constitutive androstane receptor, and orphan nuclear receptor hepatocyte nuclear factor 4alpha in the regulation of human steroid-/bile acid-sulfotransferase. Mol Endocrinol 2007, 2 I:2099-2 | | |.

13. Popowski K, Eloranta J, Saborowski M, Fried M, Meier PJ, Kullak Ublick GA: The human organic anion transporter $\mathbf{2}$ gene is transactivated by hepatocyte nuclear factor-4\{alpha\} and suppressed by bile acids. Mol Pharmacol 2005, 67:1629-1638.

14. Saborowski M, Kullak-Ublick GA, Eloranta JJ: The Human Organic Cation Transporter I Gene is Transactivated by Hepatocyte Nuclear Factor-4\{alpha\}. J Pharmacol Exp Ther 2006, 3 I 7:778-785.

15. Qadri I, Hu LJ, Iwahashi M, Al Zuabi S, Quattrochi LC, Simon FR: Interaction of hepatocyte nuclear factors in transcriptional regulation of tissue specific hormonal expression of human multidrug resistance-associated protein 2 (abcc 2 ). Toxicol Appl Pharmacol 2009, 234:281-292.

16. Douet V, VanWart CM, Heller MB, Reinhard S, Le Saux HNF4alpha and NF-E2 are key transcriptional regulators of the murine Abcc6 gene expression. Biochim Biophys Acta 2006 , I 759:426-436.

17. Sumi K, Tanaka T, Uchida A, Magoori K, Urashima Y, Ohashi R, et al.: Cooperative interaction between hepatocyte nuclear factor 4 alpha and GATA transcription factors regulates ATP-bind ing cassette sterol transporters ABCG5 and ABCG8. Mol Cell Biol 2007, 27:4248-4260.

18. Lim L, Zhou H, Costa $\mathrm{RH}$ : The winged helix transcription factor HFH-4 is expressed during choroid plexus epithelial development in the mouse embryo. Proc Natl Acad Sci USA 1997, 94:3094-3099.

19. Strazielle N, Ghersi-Egea JF: Choroid plexus in the central nervous system: biology and physiopathology. I Neuropathol Exp Neurol 2000, 59:56I-574.
20. Borlak J, Zwadlo C: Expression of drug-metabolizing enzymes, nuclear transcription factors and ABC transporters in Caco2 cells. Xenobiotica 2003, 33:927-943.

21. Niehof M, Borlak J: RSK4 and PAK5 Are Novel Candidate Genes in Diabetic Rat Kidney and Brain. Mol Pharmacol 2005, 67:604-6II.

22. Niehof M, Borlak J: HNF4\{alpha\} and the Ca-Channel TRPCI Are Novel Disease Candidate Genes in Diabetic Nephropathy. Diabetes 2008, 57:1069-1077.

23. Hayhurst GP, Lee YH, Lambert G, Ward JM, Gonzalez FJ: Hepatocyte nuclear factor 4alpha (nuclear receptor $2 \mathrm{AI}$ ) is essentia for maintenance of hepatic gene expression and lipid homeostasis. Mol Cell Biol 200I, 2I:1393-|403.

24. Odom DT, Zizlsperger N, Gordon DB, Bell GW, Rinaldi NJ, Murray $\mathrm{HL}$, et al: Control of Pancreas and Liver Gene Expression by HNF Transcription Factors. Science 2004, 303: I 378-I38I.

25. Chiba H, Gotoh T, Kojima T, Satohisa S, Kikuchi K, Osanai M, et al.: Hepatocyte nuclear factor (HNF)-4alpha triggers formation of functional tight junctions and establishment of polarized epithelial morphology in $\mathbf{F 9}$ embryonal carcinoma cells. Exp Cell Res 2003, 286:288-297.

26. Chiba H, Itoh T, Satohisa S, Sakai N, Noguchi H, Osanai M, et al.: Activation of $\mathrm{p} 2$ I (CIPI/WAFI) gene expression and inhibition of cell proliferation by overexpression of hepatocyte nuclear factor-4alpha. Exp Cell Res 2005, 302: I I-2 I.

27. Battle MA, Konopka G, Parviz F, Gaggl AL, Yang C, Sladek FM, et al: Hepatocyte nuclear factor 4alpha orchestrates expression of cell adhesion proteins during the epithelial transformation of the developing liver. Proc Natl Acad Sci USA 2006, 1 03:8419-8424.

28. Torres-Padilla ME, Fougere-Deschatrette C, Weiss MC: Expression of HNF4alpha isoforms in mouse liver development is regulated by sequential promoter usage and constitutive $3^{\prime}$ end splicing. Mech Dev 200I, I09:183-193.

29. Niehof M, Borlak J: EPS I 5R, TASPI, and PRPF3 are novel disease candidate genes targeted by HNF4alpha splice variants in hepatocellular carcinomas. Gastroenterology 2008 , I34: I | $91-1202$

30. Tanaka T, Jiang S, Hotta H, Takano K, Iwanari H, Sumi K, et al:: Dysregulated expression of $P I$ and $P 2$ promoter-driven hepatocyte nuclear factor-4alpha in the pathogenesis of human cancer. J Pathol 2006, 208:662-672.

31. Hansen SK, Parrizas M, Jensen ML, Pruhova S, Ek J, et al: Genetic evidence that HNF-I \{alpha\}-dependent transcriptional control of HNF-4\{alpha\} is essential for human pancreatic $\{$ beta\} cell function. I Clin Invest 2002, I I 0:827-833.

32. Costa RH, Van Dyke TA, Yan C, Kuo F, Darnell JE Jr: Similarities in transthyretin gene expression and differences in transcription factors: liver and yolk sac compared to choroid plexus. Proc Natl Acad Sci USA 1990, 87:6589-6593.

33. Lucas B, Grigo K, Erdmann S, Lausen J, Klein-Hitpass L, Ryffel GU: HNF4alpha reduces proliferation of kidney cells and affects genes deregulated in renal cell carcinoma. Oncogene 2005, 24:64I8-643I.

34. Garrison WD, Battle MA, Yang C, Kaestner KH, Sladek FM, Duncan SA: Hepatocyte nuclear factor 4 alpha is essential for embryonic development of the mouse colon. Gastroenterology 2006 I30: | 207- | 220

35. Loscher W, Potschka $\mathrm{H}$ : Role of multidrug transporters in pharmacoresistance to antiepileptic drugs. I Pharmacol Exp Ther 2002, 30I:7-14

36. Potschka H, Fedrowitz M, Loscher W: Multidrug resistance protein MRP2 contributes to blood-brain barrier function and restricts antiepileptic drug activity. J Pharmacol Exp Ther 2003, 306: $|24-| 3 \mid$

37. Dagenais C, Graff CL, Pollack GM: Variable modulation of opioid brain uptake by $\mathbf{P}$-glycoprotein in mice. Biochem Pharmacol 2004, 67:269-276.

38. El Ela AA, Hartter S, Schmitt U, Hiemke C, Spahn-Langguth H, Langguth P: Identification of P-glycoprotein substrates and inhibitors among psychoactive compounds-implications for pharmacokinetics of selected substrates. J Pharm Pharmacol 2004, 56:967-975

39. Doran A, Obach RS, Smith BJ, Hosea NA, Becker S, Callegari E, et al.: The impact of P-glycoprotein on the disposition of drugs targeted for indications of the central nervous system: evalua- 
tion using the MDRIA/IB knockout mouse model. Drug Metab Dispos 2005, 33:165-174.

40. Szakacs G, Varadi A, Ozvegy-Laczka C, Sarkadi B: The role of ABC transporters in drug absorption, distribution, metabolism, excretion and toxicity (ADME-Tox). Drug Discov Today 2008, 1 3:379-393.

4I. Brady JM, Cherrington NJ, Hartley DP, Buist SC, Li N, Klaassen CD: Tissue distribution and chemical induction of multiple drug resistance genes in rats. Drug Metab Dispos 2002, 30:838-844.

42. Choudhuri S, Cherrington NJ, Li N, Klaassen CD: Constitutive expression of various xenobiotic and endobiotic transporter mRNAs in the choroid plexus of rats. Drug Metab Dispos 2003 3 I:I337-I 345

43. Rao VV, Dahlheimer JL, Bardgett ME, Snyder AZ, Finch RA, Sartorelli AC, et al:: Choroid plexus epithelial expression of MDRI $\mathbf{P}$ glycoprotein and multidrug resistance-associated protein contribute to the blood-cerebrospinal-fluid drug-permeability barrier. Proc Natl Acad Sci USA 1999, 96:3900-3905.

44. Smith AJ, van Helvoort A, van Meer G, Szabo K, Welker E, Szakacs G, et al:: MDR3 P-glycoprotein, a phosphatidylcholine translocase, transports several cytotoxic drugs and directly interacts with drugs as judged by interference with nucleotide trapping. J Biol Chem 2000, 275:23530-23539.

45. Wijnholds J, deLange EC, Scheffer GL, Berg DJ van den, Mol CA, van $\mathrm{d} V$, et al: Multidrug resistance protein I protects the choroid plexus epithelium and contributes to the blood-cerebrospinal fluid barrier. J Clin Invest 2000, 105:279-285.

46. Gazzin S, Strazielle N, Schmitt C, Fevre-Montange M, Ostrow JD, Tiribelli $C$, et al: Differential expression of the multidrug resistance-related proteins $A B C b I$ and $A B C c l$ between blood-brain interfaces. I Comp Neurol 2008, 5 I 0:497-507.

47. Scotto KW: Transcriptional regulation of $\mathbf{A B C}$ drug transporters. Oncogene 2003, 22:7496-75II.

48. Eloranta |J, Kullak-Ublick GA: Coordinate transcriptional regulation of bile acid homeostasis and drug metabolism. Arch Biochem Biophys 2005, 433:397-4I2.

49. Kamiyama Y, Matsubara T, Yoshinari K, Nagata K, Kamimura H, Yamazoe $Y$ : Role of human hepatocyte nuclear factor 4alpha in the expression of drug-metabolizing enzymes and transporters in human hepatocytes assessed by use of small interfering RNA. Drug Metab Pharmacokinet 2007, 22:287-298.

50. Dignam JD, Lebovitz RM, Roeder RG: Accurate transcription initiation by RNA polymerase II in a soluble extract from isolated mammalian nuclei. Nucleic Acids Res 1983, I I: I 475- I 489.

5I. Smith PK, Krohn RI, Hermanson GT, Mallia AK, Gartner FH, Provenzano MD, et al:: Measurement of protein using bicinchoninic acid. Anal Biochem 1985, 150:76-85.

52. Kel A, Reymann S, Matys V, Nettesheim P, Wingender E, Borlak J: A novel computational approach for the prediction of networked transcription factors of aryl hydrocarbon-receptorregulated genes. Mol Pharmacol 2004, 66:I557-1572.
Publish with Bio Med Central and every scientist can read your work free of charge

"BioMed Central will be the most significant development for disseminating the results of biomedical research in our lifetime. "

Sir Paul Nurse, Cancer Research UK

Your research papers will be:

- available free of charge to the entire biomedical community

- peer reviewed and published immediately upon acceptance

- cited in PubMed and archived on PubMed Central

- yours - you keep the copyright
BioMedcentral 